\title{
HouseHOLD SAVING RATES AND THE DESIGN OF SOCIAL SECURITY PROGRAMMES: EVIDENCE FROM A COUNTRY PANEL
}

\author{
RICHARD DISNEY
}

CESIFO WORKING PAPER No. 1541

CATEgory 3: Social Protection

SEPTEMBER 2005

\footnotetext{
An electronic version of the paper may be downloaded - from the SSRN website: www.SSRN.com

- from the CESifo website: www.CESifo-group.de
} 


\title{
HOUSEHOLD SAVING RATES AND THE DESIGN OF SOCIAL SECURITY PROGRAMMES: EVIDENCE FROM A COUNTRY PANEL
}

\begin{abstract}
I argue that the offsetting effect of social security contributions on household retirement saving depends on how closely the social security programme imitates a private retirement saving plan (i.e. the 'actuarial' component of the social security programme) - the closer the design of the programme to a private retirement saving plan, the higher the offset. I estimate the determinants of household saving rates in a cross-country panel, augmenting standard measures of social security programme generosity and cost by indicators that proxy the actuarial component of the programme. These indicators affect saving rates as predicted; moreover they also affect labour force participation rates of older women (but not men). The findings are consistent with the view that more actuarially-based public programmes are treated by participants as a mandatory saving programme rather than as a tax-and-transfer system, thereby raising labour force participation rates but also increasing the programme's substitutability for private retirement saving.
\end{abstract}

JEL Code: E21, G23, H24.

Keywords: social security reform, household saving.

\author{
Richard Disney \\ Sir Clive Granger Building \\ University of Nottingham \\ University Park \\ Nottingham, NG7 2RD \\ $U K$
}

My thanks to participants in an IZA Conference in Lisbon and the CESifo/CEBR conference in Copenhagen, and to Giuseppe Bertola, Tullio Jappelli and Gulglielmo Weber for useful comments at various stages in this paper's preparation. 


\section{Household saving rates and the design of social security programmes: evidence from a country panel}

\section{Introduction}

Basic life cycle theory and a large empirical literature argue that social security programmes, which provide benefits after a certain age financed out of general or hypothecated taxes on households, affect the behaviour of those households. First, publicly-provided retirement income affects the propensity of households to engage in private retirement saving and also their wealth decumulation strategy later in life. Second, by driving a wedge between the pre- and post-tax wage, social security affects the gains from work and therefore the optimal length and intensity of the working life, as well as providing specific disincentives to economic activity in later life. Although studies differ in what they are testing and how they test it, there seems to be general agreement that social security affects household behaviour in direct proportion to the average level of social security taxes (as a large component of the tax 'wedge'), in proportion to the generosity of the social security programme (the average 'replacement rate') and in relation to any specific disincentives to work and save late in life (e.g. retirement tests, income and wealth-testing of social security benefits, and the like).

In all this discussion of the impact of the scale and magnitude of the effects of social security, rather less attention has been paid in the empirical literature as to how the design of social security programmes affects these dimensions of household economic activity. In fact, social security programmes vary substantially in their provisions - not just in terms of average generosity but also in, for example, how closely individual social security entitlements are related to individual contributions, in generational differences in the implicit 'rate of return' on contributions relative to rates of return available in the capital market, and so on. The implications of programme heterogeneity for household behaviour have not always been thought through in the existing literature, and variations across countries and over time have certainly not been exploited (to my knowledge) to test the underlying theory.

To illustrate the general point: some recent social security reforms (notably in Germany, Italy and Sweden) have been designed explicitly to make the social security programme 'fairer' in some actuarial sense (i.e. so that individual benefits are more 
closely matched to individual contributions). There is an implicit assumption that this will 'improve incentives' and thereby affect household behaviour. In effect, making a public tax-financed social security programme appear to be like a private retirement saving plan may cause individuals to interpret social security contributions less as a tax and more as a mandatory saving contribution. This perception may have the effect of ameliorating the perceived 'tax wedge' aspect of the programme, albeit at the expense of making social security benefits closer substitutes for private retirement saving and thereby potentially reducing private retirement saving.

In contrast, greater targeting of social security benefits on poorer pensioners (as has happened in, for example, the United Kingdom) will certainly increase the disincentives both to save and to work later in life for prospective recipient households but, by making the programme look less like an actuarial programme, have quite different effects on other, better-off, groups in the population. The net effect on incentives to save and work later in life may go in either direction depending on the exact design features of the programme, preferences, rates of return and so on (Feldstein, 1987).

This paper attempts to fill a gap in the existing literature. It examines how actual variation in the design of social security programmes across countries and time affects different dimensions of economic activity of households, but particularly household retirement saving. In the absence of any large volume of literature on this topic (see Section 3 for a discussion of what literature there is), there are two broad ways of tackling this issue. First, we can match exact prospective benefit entitlements to individual households and investigate whether differences in household behaviour or in prospective behaviour (for example, the current saving rate, prospective retirement date etc.) correlate with these projected benefit entitlements. Few, if any, data sets of this type exist and in any event they beg the question of whether people understand the programme in sufficient detail to be able to make projections of their own benefits (or benefit-cost ratios) based on current criteria (and indeed, on forecasts of future government policy). ${ }^{1} \quad$ In addition, snapshots of household behaviour cannot exploit variation in pension regimes across time or country to examine behavioural responses.

The second broad approach, which is adopted here, is to assume that households understand the general provisions of the programmes to which they contribute. They

1 See Dominitz, Manski and Heinz (2003) for an explicit attempt to model household pension expectations in the United States and, for a more general discussion of pension expectations in several countries, Boeri, Börsch-Supan and Tabellini (2001). 
broadly understand, for example, whether programme benefits and contributions are earnings-related or, Beveridge-style, designed to provide a basic income floor. Moreover, households understand what, in general terms, they pay into the programme relative to what they expect to get out of it. Using a representative-household approach, we can then exploit cross-country and cross-time period variation in the average characteristics of programmes in order to examine differences in aggregate (or age-specific) economic activity rates, saving rates etc. The paper shows that the design of the programme, in the twin senses of variations in within-cohort and across-cohort 'returns' on contributions, do indeed affect household saving rates and economic activity rates (at least, of certain groups in the labour market). As such, the study extends in a new direction the existing work (from OECD and others) that simply focuses on the effect on these aggregates of the average generosity and budgetary costs of social security programmes.

The next section of the paper briefly examines the design of social security programmes in a standard framework. It then suggests how design differences might be expected to affect various dimensions of household behaviour, a priori. It also surveys the existing empirical literature (most of which ignores programme design issues completely). Section 3 then provides a brief account of the construction of the key variables; an issue more extensively discussed in my earlier attempt to examine the economic activity (labour force participation) dimension (Disney, 2004). Section 4 contains econometric evidence which shows quite clearly that social security programme design matters; moreover, careful specification of these design features appears to obtain greater precision in the estimate of the average effect of social security - notably of the degree of 'saving offset' arising from the social security programme - as well as the effect of the 'tax wedge' on employment. Section 5 then summarises the main conclusions of the paper.

\section{Theory and existing literature}

\subsection{Some basic analytics}

This sub-section derives a simple two period OLG model, broadly following the notation of Lindbeck and Persson (2003). Generations are denoted by $t, t+1$ and periods of the life are denoted $i=1,2$. The individual consumer/household works in period 1 and is retired in period 2, with known date of mortality and no bequests. 
Suppose that there is a social security programme paying benefit $b$ in the second period and financed by a payroll tax proportional income tax in period 1 levied at rate $\tau$. Second period consumption can then be written as:

$$
c_{t}^{2}=\left[y_{t}^{1}(1-\tau)-c_{t}^{1}\right](1+r)+b
$$

where $c$ is consumption and $r$ is the rate of interest, and $y$ is labour income where $y=w l ; w$ is the wage rate and $l$ is some measure of lifetime labour supply. Assuming that the individual cannot borrow in period 1 against future social security income, second period consumption is determined by first period saving, by the real rate of interest, and by the size of the social security benefit.

Assume that the social security programme is financed on a pay-as-you-go (PAYG) basis - that is, out of current taxation. Again following the standard notation, write:

$$
n_{t} \hat{b}_{t}=\tau_{t+1} n_{t+1} \hat{w}_{t+1} \hat{l}_{t+1}
$$

where hats over variables denote population averages and $n$ denotes the size of the generation. This simply states that the total value of benefits paid is equal to the payroll tax rate times the total wage bill. The average 'return' on contributions for a member of generation $t$ can be written as:

$$
\hat{b}_{t} / \tau_{t} \hat{w}_{t} \hat{l}_{t}=(1+G)
$$

This states that the internal rate of return on contributions, G, depends on the average stream of benefits relative to the average total value of contributions paid by a member of that generation. Substituting for $b$ in (2), denoting $n_{t+1} / n_{t}$ as $(1+n)$ and $\hat{w}_{t+1} / \hat{w}_{t}$ as $(1+g)$, write:

$$
\frac{\tau_{t+1} \hat{l}_{t+1}}{\tau_{t} \hat{l}_{t}}(1+n)(1+g)=(1+G)
$$

With a constant tax rate and a constant labour force participation rate, we get the standard Aaron-Samuelson result that the sustainable long run 'return' on social security contributions, $G^{*}$, is approximately equal to the growth of population and the growth of real wages. With dynamic efficiency, this rate should normally be less than $r$, and this discrepancy is sometimes called the 'implicit tax' associated with PAYG finance of social security. However, if governments can increase the participation rate of contributors 
within the social security programme, or else levy ever-increasing tax rates, $G$ will temporarily exceed $G^{*}$ for a period of time and for particular generations (this is especially likely for the earliest generations in a newly-instituted programme).

This paper argues that the design of the social security programme has implications for the potential impact of the programme on labour supply and on saving. To illustrate this simply, I continue to assume that the payroll tax, $\tau$, is proportional to the wage, and that specific design features can be illustrated through the formulation of the social security benefit, $b$. Assume, therefore, that the social security benefit is part'Beveridge' and part-'Bismarck' along the lines described by Casamatta, Cremer and Pestieau (2000), as in (5):

$$
\hat{b}_{t}=\alpha(1+G) \tau y_{t}+(1-\alpha) \bar{b}
$$

Here, the average benefit paid is composed of two components. The first component, weighted by $\alpha$, is the fraction of the benefit that is proportional to earnings and earns the average 'return' on contributions G. This is the 'Bismarck' component of the programme. The second component, weighted by $(1-\alpha)$, pays a flat benefit $\bar{b}$ (or some other formula) entirely unrelated to individuals' contributions to the programme. This is the 'Beveridge' component of the programme.

Substituting (5) into second period consumption in (1), we get:

$$
c_{t}^{2}=y_{t}^{1}\left[1-\frac{(1+r-\alpha(1+G))}{(1+r)} \tau-c_{t}^{1}\right](1+r)-(1-\alpha) \bar{b}
$$

To see what implications this programme design has for the average tax rate on the individual, we can consider several simplifications of this rather cumbersome formula. Suppose first that $r=G$ and $\alpha=1$. This is the case where the public programme effectively imitates a private retirement saving programme - the last term and the term in $\tau$ drop out. So long as the mandatory retirement saving rate through the public programme does not exceed the saving that the individual would have undertaken himself or herself, the programme has no impact on individual labour force participation and there should be a one-to-one offset on private retirement saving.

A straightforward simplification also arises if we assume $r=G$ but that $0<\alpha<$ 1. The programme departs from actuarial fairness only insofar as part of the pension benefit paid by the programme is unrelated to individual contributions. The lack of 
actuarial fairness can be measured by differences in replacement rates across individuals within a generation i.e. a departure from an actuarial basis to the programme in an intragenerational sense. (6) then simplifies to:

$$
c_{t}^{2}=y_{t}^{1}\left[1-(1-\alpha) \tau-c_{t}^{1}\right](1+r)-(1-\alpha) \bar{b}
$$

Therefore, the greater the degree to which the system departs from actuarial fairness, as measured by $(1-\alpha)$, the higher the 'tax component' of the social security contribution, $\tau$.

Conversely, suppose $r \neq G$ and $\alpha=1$. I term this a departure from intergenerational equity insofar as average 'returns' to contributors differ across generations. (6) then becomes:

$$
c_{t}^{2}=y_{t}^{1}\left[1-\frac{(r-G)}{(1+r)} \tau-c_{t}^{1}\right](1+r)
$$

The average tax component of the contribution is simply the difference between the return on saving and the 'return' on social security contributions as defined by (3).

In practice, social security programme contributions contain a 'tax component' arising from departures from both actuarial fairness and intergenerational equity, although the extent of these relative deviations depends on the design of the programme. It is measuring these departures from an actuarial programme, and measuring the impacts of these divergences on labour supply and saving behaviour, that form the empirical part of the paper.

\subsection{Impact of the social security programme on household saving}

The argument that social security contributions reduce household saving rates is straightforward. If contributions to a social security programme are a perfect substitute for private retirement saving, social security contributions should offset private saving one to one. However there are various well known caveats to this interpretation of social security contributions. First, some private saving may not be for retirement (e.g. for buffer stock or precautionary motives) and so measured offset coefficients may be lower. Second, where mandatory saving (i.e. contributions to the public programme) exceeds that which the individual would have done in the absence of the public programme, lifetime consumption as well as saving may be affected. Third, there are various issues 
concerning the correct measurement and interpretation of private saving, especially when we consider the decumulation phase of funded private pensions and indeed social security itself (e.g. Jappelli and Modigliani, 2003).

The preceding analysis suggests that the design of the social security programme should have an impact on the extent of the saving offset. In the intergenerational comparison, the closer the programme is to a saving programme (i.e. where $R=g$ ), the greater the potential offset for private saving because of the substitutability between contributions to the social security programme and a private retirement saving plan (leaving aside differences in the risk characteristics of the respective portfolios).

Where the public programme departs from an actuarial pension plan in an intragenerational sense, the analysis of the potential offset effect is more complicated. If the public programme is highly redistributive within a generation towards lower earners, poorer households will have an incentive to save less, whereas higher earners do not receive a return on their contributions equivalent to a private retirement plan and their saving will be hardly affected. The offset should therefore be highest among low earners. But since, as a matter of fact, most private saving is done by high lifetime earners, the average measured offset should be lower the higher the degree of redistribution within the programme. The only qualification to this is if the programme differentially affects the retirement behaviour of high and low income earners (see Section 2.2.2 below).

\subsubsection{Empirical evidence on the saving offset from social security programmes}

There is a substantial empirical literature on how contributions to social security programmes affect private saving rates. ${ }^{2}$ Several studies calculate prospective social security entitlements across households and examine whether these values are associated with differences in household saving rates (as in, for example, Hubbard, 1986, Alessie, Kapteyn, and Klijn, 1997). Results are sensitive to the calculation of expected pension wealth and the measures used to calculate prospective wealth (e.g. current and predicted earnings) are likely also to exert an independent effect on household saving; moreover, there has to be regime variation to examine differences in behaviour across alternative types of programmes.

Kotlikoff (1979) used cross section data from a sample of US heads of households aged 45-59 in 1966 to examine the impact of social security wealth or

\footnotetext{
2 For a selective survey, see Disney (2000a).
} 
household private net worth. He measured both the value of accumulated social security taxes (ASST) and the value of net SSW. He found that household net worth was negatively correlated with the value of accumulated social security taxes (coefficient $=$ -0.67). This implies that payments of social security taxes are at least partly perceived as providing a future entitlement to a retirement pension, but the coefficient on his net SSW measure on saving was positive and insignificant which, he argued "...cast doubt on the ability of people to accurately project their Social Security benefits and their age of retirement; large differences in lifetime wealth generated by the social security system do not appear to influence savings" (ibid. p.408).

A few recent studies do explore the promising avenue of using pension regime changes in order to measure offsets of private retirement saving arising from social security programmes using household data, notably Attanasio and Brugiavini (2003) and Bottazzi, Jappelli and Padula (2004) for Italy and Attanasio and Rohwedder (2003) for the UK, but such studies are relatively unusual and generally limited to one 'reform'.

Most studies of the 'offset' between social security programmes and private saving therefore use either time series methods, or country cross sections, or a combination thereof. The seminal paper by Feldstein (1974) estimated a time series model of consumption spending regressed on income, social security wealth (SSW; both gross and net of contributions) and other household wealth for the US economy 192971. From it, he calculated that total private household saving was approximately halved by social security wealth. This article spawned a good deal of controversy concerning methodology, data and estimation methods. A flaw in the programming was subsequently corrected (e.g. Feldstein, 1996) but Leimer and Lesnoy (1982) argued that the measure of the replacement ratio should take account of the cohort-by-cohort variation in expected RRs rather than simply assuming a constant RR as Feldstein did (bar the major change in benefit rules that occurred in 1972). With the revised specifications, they found no offset between SSW and saving.

Another influential paper for the present analysis from this early literature is that of Feldstein (1987) who calculates the trade-off for various parameter values between a means-tested social security programme that encourages some households to stop retirement saving completely but which requires a lower contribution rate, and a comprehensive Bismarck-style earnings-related programme that requires a higher contribution rate and which encourages all participants to reduce their retirement saving 
by some fraction. In general, his simulations suggest that the net impact on household saving will be higher in a comprehensive social security programme (that is where $\alpha$ and $\tau$ are higher, in the terminology of Section 2) than in programmes where benefits are specifically targeted, although of course in the latter case some households will not save at all in order to avoid the prospective impact of the means test in retirement.

Finally, we can note that several papers approach the issue of social security programmes and retirement saving using cross-country data sets, with mixed results. Early studies such as Barro and MacDonald (1979) and Koskela and Viren (1983) found no evidence that more generous social security programmes (proxied simply by social security/GDP ratios with additional demographic controls) reduce household saving, although the latter study found evidence that more generous public pensions reduce economic activity of the 65 and over age group. In contrast, a short panel analysis of 12 OECD countries by Feldstein (1980) suggests that a ' $10 \%$ percentage increase in the benefit-to-earnings ratio reduces the saving rate by approximately 3 percentage points' (ibid, p.236). More recently, Callen and Thimann (1997) suggest that demographic dependency, the ratio of direct taxes to GDP and the ratio of gross transfers to GDP all have adverse effects on household saving in a long panel of 21 OECD countries, although social security generosity is not included among the variables. Recent studies with greater samples of countries and greater econometric sophistication (e.g. Loayza et al, 2000) find evidence that private and household savings rates are affected by demographics but do not include any variables that reflect social security wealth or other proxies. No studies, therefore, to the author's knowledge, utilise social security programme design as a variable in cross country estimates of the determinants of household saving.

\subsubsection{The induced retirement effect}

As was also noted by Feldstein (1974), the impact of social security on household saving may be offset by specific incentives within the social security programme to retire earlier (such as retirement tests for eligibility, and the like), so requiring higher household wealth at the date of the retirement. This was his explanation for the weak and indeed sometimes positive correlation found between household saving and social security wealth in time series and cross section studies.

More generally, however, social security programmes may affect household labour force participation through the direct effect of social security taxes on the 'return' 
from work. In another seminal contribution, Sheshinski (1978) shows that, with a proportional contribution rate, a more generous social security programme financed by payroll contributions will lead to a shorter working life so long as entitlement to social security benefits is independent of contributions paid. This result arises because, in an optimal retirement model, the individual chooses the retirement age at which the marginal utility from leisure is equated to the marginal net wage. It is of interest to note in the present context that Sheshinski postulates that this induced retirement effect will be smaller if benefits are more closely linked to contributions.

Most standard economic analyses of the impact of social security on employment however completely by-pass the issue of prospective future benefits and simply treat current social security contributions as a pure tax by including it in the 'tax wedge'. Representative studies of employment or unemployment that use cross-country panel data include Nickell and Layard (1999), Blanchard and Wolfers (2000) and Nickell, Nunziata and Ochel (2005). Most of these studies focus on institutional features of the various economies, but not on the design of the social security programme per se. Contributions to social security programmes are simply treated as taxes and often measured at face value even though, for example, several countries do not levy separate hypothecated social security contributions. Not surprisingly, studies find little robust evidence of a relationship between average social security contributions and economic activity or unemployment rates.

The nearest discussion in the literature to that of the present paper is in how institutional differences affect social security contribution incidence - see OECD (1990) and Nickell (2004). If the worker bears the incidence of the tax, then the wedge between the pre-tax and post-tax wage will affect participation in and hours supplied to the formal economy so long as labour supply is not completely inelastic (OECD, 1990). This could happen through changes in hours supplied in response to changes in the structure of marginal contribution rates and to the indexation provisions of out-of-work benefits (as in Pissarides, 1998), changes in the optimal length of the working life as described previously, and if higher payroll taxes give incentives for workers, in collusion with employees, to leave the formal economy and to engage in various untaxed activities. Alternatively, if workers have some market power and are able to pass the incidence of the payroll tax through to consumers via product prices (at least in part), there will be a direct adverse impact on product demand and therefore on the derived demand for labour. In a unionised open economy, a higher employment tax is partly shifted onto 
employers if unions obtain a higher nominal wage. Assuming prices are set as a markup over unit costs, the consequent rise in product prices both reduces real expenditure and also leads to a substitution of demand towards competing products (imports). Employment falls irrespective of the elasticity of supply of labour.

In contrast, in the analysis presented here and in Disney (2004), the labour supply effect depends on the tax component of the social security contribution rather than the whole contribution. The intergenerational tax component arises insofar as the lower is $G$ relative to $r$, the greater the penalty to lifetime incomes arising from mandatory social security contributions and therefore the greater the potential adverse impact on employment. The greater the intragenerational departure from actuarial fairness (that is, the lower is $\alpha$ in (5)), then, assuming that the departures from an actuarial programme broadly involve redistribution towards those with lower lifetime pre-tax incomes, higher income earners face a higher-than-average tax rate in the form of social security contributions that is not fully compensated by post-retirement benefits. This acts as a disincentive to participation in the programme. For lower earners, there $i s$ an incentive to participate in the social security programme, but the higher pensions than would otherwise have been obtained in an actuarial programme could again induce these workers to retire early.

The only other contribution that notes that social security design might affect employment differentially is that of Ooghe, Schokkaert and Flechet (2003). Although using data for only 6 countries and a rather crude measure of 'Beveridge' v. 'Bismarck' in proxying design features of public programmes, they provide some tentative evidence that contributions are shifted on to employees to a greater extent in Bismarckian programmes (that is, with a higher value of $\alpha$ in equation (5) above). This is compatible with the view (in this dimension at least), that in programmes that more closely match benefits to contributions, employees treat contributions more like a mandatory saving programme and less like a tax.

\section{Empirical estimates}

\subsection{Data and methods: core variables}

The empirical analysis here is conducted for 21 OECD countries for which consistent data are available over a long period. The household saving rate as a percentage of GDP is taken from IMF sources (primarily cited in Callen and Thimann, 
1997), updated from the OECD database. The age-activity rate, as a percentage of the population in each age group, is derived from the ILO online statistical database.

We assume a 'representative agent' considering future retirement in each country in three periods: the 1970s, 1980s and 1990s (I take mid-points of the decades) and define the variables in turn. The average social security replacement rate (Pension RR) uses rates calculated by Blöndal and Scarpetta (1998). These rates are projected replacement rates for workers in their mid-50s, when they subsequently retire, for each period and country (the authors provide several replacement rates at each point in time, the variation in which is also exploited - see below).

I do not use actual reported social security programme contribution rates, as these are often notional rates (including zero). Instead, I use data from the ILO (with some adjustments, described in the Appendix to the present paper) to construct ratios of workers to pensioners in each period (see Appendix Table A1; this is the variable support ratio in some tables below). Given the average replacement rates from Blöndal and Scarpetta, these support ratios can then be used to calculate 'effective' contribution rates using equation (2) above - these are the contribution rates that are effectively being levied to finance the current outgoings of the social security programme given the demographics and expected current replacement rates. These calculated values, described in Table A2, are the contribution rate used in the later empirical estimates. Note that estimates of internal rates of return to pension contributions (see below) require that this calculation of contribution rates be made for each decade from the 1950s to the 1990s.

Several variables are used to capture the design features of the social security programme. The first, termed a pension tax, is designed to measure the deviations of rates of return within cohorts arising from variations in replacement rates across household types. It is intended to capture the term $(1-\alpha)$ in equation (5), and therefore to measure departures from what I termed intragenerational 'actuarial fairness' in Section 2. To construct the variable, I calculate the coefficient of variation of replacement rates across several household types in the same country and year (delineated by level of income and number of people in the household) using the data contained in Blöndal and Scarpetta (1998) for several household types. If every household type receives the same replacement rate, the value is zero; the highest value is for Australia in 1995, where the 
coefficient of variation is almost $0.4 .^{3}$ This coefficient of variation, multiplied by the average contribution rate, gives the variable pension tax.

The second variable is intended to capture differences in intergenerational rates of return over time and country, and involves rather more computation. It is termed IRR at 65 in the ensuing tables, and involves estimating, for a representative agent in each country and period, the expected internal rate of return from retiring at age 65, akin to the $G$ in equation (3) above. ${ }^{4}$ The method of constructing these internal rates of returns is described in a little more detail in the Appendix. It extrapolates the average replacement rates constructed by Blöndal and Scarpetta (1998) to construct expected pension replacement rates for three cohorts born in 1920, 1930 and 1940 and, therefore, broadly retiring in the mid 1980s, 1990s and 2000s. The method then utilises the effective average contribution rates constructed as described previously for each decade since 1950 to the 1990 s, taken at midpoints.

Given contribution rates over time, calculating internal rates of return for our three cohorts for the 21 countries is reasonably straightforward. In each decade, the contribution rate is applied to average earnings, which grow in each decade in real terms (the earnings index is obtained from OECD data). It is assumed that the first cohort, born 1920, only starts contributing in 1950 (to capture the advantage accruing to the earliest generation) but that subsequent generations contribute until they are aged 65 . This gives the total value of contributions paid. The replacement rate is then applied to real earnings at retirement, and the pension is increased in line with subsequent earnings growth if earnings indexation is in place. Expected age of death is taken from Blöndal and Scarpetta (checked on ILO data) with survivors' benefits paid at the appropriate rate for that country until the spouse's expected age of death.

The internal rate of return is then computed as that rate of return at which the present value of the (negative) stream of contributions paid is equal to the present value of the (positive) stream of pension benefits. Appendix Table A3 gives the calculated values. Note the wide variations across countries but the almost universal fall in IRRs after the first decade. At just over 1\%, the average IRRs for the generations born in 1930 and 1940, are likely to be well below $r$ in equation (1), illustrating the 'implicit tax'

3 Other higher values of this 'pension tax' include New Zealand, the UK and Ireland, all of which have 'Beveridge'-type pension regimes. See Disney (2004) for graphical illustrations.

4 Of course, actual average retirement age is typically less than age 65 but will be endogenous to the economic activity and saving rates, which we want to explain, so I use IRR at $\mathbf{6 5}$ as a proxy for this. For a comparison of calculations of average IRRs at average expected retirement ages and calculated IRRs at age 65, see Disney (2004). 
from PAYG financing and the above-average returns obtained by the first generation. However actual cohort IRRs have typically been higher than those calculated in Table A3 because individuals have been permitted to retire earlier than age 65 (see Disney, 2004, for evidence and discussion). I also use these IRRs at actual expected retirement dates as an alternative indicator variable.

The correlation matrix for these measures of social security programme design are described below. There is a strong positive correlation between the average generosity of the programme, as measured by Pension RR, and the contribution rate. Remembering that the latter is calculated from applying equation (2) above using the support ratio and the average replacement rate, this tells us that variations in contribution rates are almost wholly driven by variations in replacement rates rather than by differences in demographics - of course the correlation of support ratios and contribution ratios is negative. So the table shows that there would be a significant collinearity problem if we were to include both replacement rates and contribution rates in the same regression (quite apart from any econometric issues arising from the construction of the latter variable).

Second, there is a negative correlation (although not so strong) between the 'pension tax' variable and the contribution rate. This simply suggests that countries with highly redistributive (Beveridge) programmes have less costly social security programmes than countries that link benefits more closely to earnings (Bismarck). Thirdly, and gratifyingly from an econometric point of view, the calculated 'IRRs at 65' do not strongly correlate with the other pension variables.

\section{Correlation coefficients for calculated variables}

\begin{tabular}{|c|c|c|c|c|c|}
\hline Correlation & $\begin{array}{c}\text { Contrib. } \\
\text { rate }\end{array}$ & $\begin{array}{c}\text { Pension } \\
\text { RR }\end{array}$ & $\begin{array}{c}\text { Pension } \\
\text { tax }\end{array}$ & $\begin{array}{c}\text { Support } \\
\text { Ratio }\end{array}$ & $\begin{array}{c}\text { IRR at } \\
\text { 65 }\end{array}$ \\
\hline $\begin{array}{c}\text { Contrib. } \\
\text { Rate }\end{array}$ & 1.0000 & - & - & - & - \\
\hline $\begin{array}{c}\text { Pension } \\
\text { RR }\end{array}$ & 0.9500 & 1.0000 & - & - & - \\
\hline Pension tax & -0.4834 & -0.5673 & 1.0000 & - & - \\
\hline $\begin{array}{c}\text { Support } \\
\text { Ratio }\end{array}$ & -0.6440 & -0.3932 & 0.0854 & 1.0000 & - \\
\hline IRR at 65 & 0.0513 & 0.1431 & -0.2586 & 0.1455 & 1.0000 \\
\hline
\end{tabular}

Two other variables characterising the social security programme are included in the regressions. The first, Retirement test index, measures the intensity with which a 
retirement test is applied to those over state pension age. This indicator variable uses information from OECD and the US Social Security Administration's description of country-specific pension programmes and takes 4 values as follows:

$0=$ no retirement or earnings test

$1=$ retirement or earnings test but deferral of pension permitted and earnings threshold for test $>0$

$2=$ retirement or earnings test but either deferral permitted or some earnings exempt from test

3 = full retirement test - pension receipt conditional on full retirement; no opportunity for deferral of pension.

The second, Earliest pension age, is the earliest age at which individuals can obtain the normal state pension, taken from the same source.

\subsection{Other variables}

Other control variables are included (although some are omitted from the illustrated specifications due to lack of significance). These include the BlanchardWolfers (2000) measure of Demand shocks, and GDP growth.

For the saving regressions, I follow Jappelli and Pagano (1994) in constructing measures of financial repression (liquidity constraints), the argument being that differential changes in the availability of finance over time across countries may also affect household saving. Jappelli and Pagano (J-P) use three indices of credit availability: consumer credit as a percentage of NNP, credit to the financial sector as a percentage of GDP, and the maximum loan-to-value ratio in house purchase. The first of these is not available for a sufficient number of countries, ${ }^{5}$ but the other two indices can be updated from a variety of sources. ${ }^{6}$ Note that 'credit to the financial sector' also include credit to firms, and that borrowing from banks by companies may be an indicator of the lack of development of an equity market rather than reflecting the lack of a credit market for consumers.

For regressions on labour force participation of older workers, the standard literature on the 'tax wedge' such as Nickell and Layard (1999) and Blanchard and Wolfers (2000) et al gives various indicators. Several of these studies have time invariant indicators of the Employment protection index, and Union density. Given that our

\footnotetext{
5 For what we do know on consumer credit across countries, see Bertola, Disney and Grant (2006). 6 From OECD Economic Outlook, the BIS, IMF Financial Statistics and HM Treasury's evaluation of the UK's housing market for the 'five economic tests' for membership of the European single currency.
} 
specifications utilise country and time dummies, only institutional differences that have time variation can be included. ${ }^{7}$

\section{Empirical estimates}

\subsection{Impact of programme design on household saving rates}

This section provides results on the impact of the design of the social security programme on household saving rates. It departs from the traditional literature in Section 3.2 in considering explicitly design parameters of the programme in addition to 'traditional' measures of cost and generosity. Note that we are here assuming that current household saving is associated with the parameters of the pension regime calculated for a person in their mid-fifties expecting to retire at 65. Clearly the household saving rate is a weighted average of the saving of all age groups, and it is a strong assumption that young savers also expect the same social security regime to be place when they retire. There are two reasons for using this approach. First, we simply do not have age-specific saving data for enough countries. Second, aggregate household saving is typically dominated by the discretionary (active) saving of people in late middle age (from standard empirical observations of the life cycle theory, as in Jappelli and Modigliani, 2003), which is exactly the point in the life cycle at which replacement rates, IRRs etc. are calculated here. ${ }^{8}$

Table 1 provides some simple descriptive statistics for the variables used in the analysis, some of which have already been described in greater detail in the previous section or in the Appendix.

Of particular note from Table 1 are the high variances of saving and contribution rates, and the range of the IRR variables and the pension (social security) replacement rate. The 'pension tax' variable is an absolute tax rate and the mean is relatively low because the countries that have low values of $\alpha$ tend to have low contribution rates ('Beveridge' countries) so that $[(1-\alpha) \times$ the contribution rate $]$ is relatively low.

7 For further discussion of time-varying indicators of labour market institutions, see Disney (2004) and Nickell, Nunziata and Ochel (2005).

8 On this last point, see the discussion of Feldstein (1974) and Leimer and Lesnoy (1982) earlier; our position of using expected replacement rates of people within a decade of retirement is perhaps midway between that of Feldstein (who uses current replacement rates of the elderly projected forward) and Leimer and Lesnoy who use actual outcomes ex post. 
Table 1

Means, standard deviations, minima and maxima of variables

\begin{tabular}{|l|cccc|}
\hline \multicolumn{1}{|c|}{ Variable } & Mean & Std. Dev. & Minimum & Maximum \\
\hline Dependent variable & & & & \\
Household saving rate (\%) & 11.4 & 6.2 & -3.6 & 24.9 \\
& & & & \\
Social security variables & & & & \\
Contribution rate (\% wage bill) & 25.1 & 9.6 & 11.6 & 57.7 \\
Pension RR (\% of wage) & 59.8 & 17.3 & 28.9 & 120 \\
Support ratio & 2.5 & 0.36 & 2.0 & 3.7 \\
Pension tax (\%) & 3.4 & 2.3 & 0.02 & 6.9 \\
IRR (\%) & 3.1 & 2.3 & -1.6 & 12.0 \\
IRR at 65 (\%) & 2.0 & 2.2 & -0.5 & 10.3 \\
Retirement test index (0 to 3) & 1.2 & 1.1 & 0 & 3 \\
Earliest pension age (years) & 61.6 & 3.4 & 55 & 68 \\
& & & & \\
Age-activity rates & & & & \\
Women 50-54 (\% of LF) & 52.9 & 17.3 & 22.7 & 87.5 \\
Women 55-59 (\% of LF) & 40.7 & 15.4 & 17.4 & 77.1 \\
Men 50-54 (\% of LF) & 89.8 & 4.1 & 79.7 & 97.5 \\
Men 55-59 (\% of LF) & 78.8 & 9.5 & 55.1 & 95.0 \\
& & & & \\
Other variables & & & & \\
Demand shock (\% $\times 100)$ & 0.2 & 7.4 & -30.6 & 14.3 \\
GDP growth (\% $\times 100)$ & 2.8 & 1.4 & -1.0 & 5.8 \\
Max LTV ratio (\%) & 76.1 & 11.7 & 50.0 & 95.0 \\
Fin credit as \% of GDP & 61.4 & 31.5 & 21.0 & 169 \\
Union density (\%) & 43.1 & 19.6 & 14.5 & 90.0 \\
Employment protection index & 2.3 & 1.1 & 0.2 & 4.0 \\
& & & & \\
\hline
\end{tabular}

Note: For list of countries and periods used, see Tables A1 to A3

As a benchmark for what follows, Table 2 provides three 'traditional' empirical specifications of the life cycle model which alternately utilise, as indicators of the social security programme's impact on the household saving rate, the social security contribution rate and the average pension (social security) replacement rate. One of the specifications includes the additional 'financial repression' variables. The standard empirical model predicts that a higher contribution rate and/or a higher pension $\mathbf{R R}$ in the social security programme (which, as we have seen, are strongly positively correlated) should reduce private household saving, with a likely 'offset coefficient' of between zero and unity. Standard life cycle theory (e.g. Modigliani, 1986) suggests that a higher support ratio raises household saving. The LCH theory also suggests that higher GDP growth should affect saving positively and positive demand shocks might increase saving in the standard permanent income framework. 
Table 2 Household saving rates, by measures of cost and
generosity of social security programme

\begin{tabular}{|c|c|c|c|}
\hline $\begin{array}{l}\text { Dep. Variable: } \\
\text { Household saving rate }\end{array}$ & $\begin{array}{c}\text { (1) } \\
\text { Coeff. } \\
\text { (Std. Err) } \\
\end{array}$ & $\begin{array}{c}\text { (2) } \\
\text { Coeff. } \\
\text { (Std. Err) } \\
\end{array}$ & $\begin{array}{c}\text { (3) } \\
\text { Coeff. } \\
\text { (Std. Err) } \\
\end{array}$ \\
\hline Contribution rate & $\begin{array}{l}0.14^{* *} \\
(0.07)\end{array}$ & - & $\begin{array}{l}0.13^{*} \\
(0.08)\end{array}$ \\
\hline Pension RR & - & $\begin{array}{r}0.06^{*} \\
(0.04)\end{array}$ & - \\
\hline Support ratio & $\begin{array}{l}4.25^{* * *} \\
(0.77)\end{array}$ & $\begin{array}{l}3.28^{* * *} \\
(0.66)\end{array}$ & $\begin{array}{l}4.34^{* * *} \\
(0.78)\end{array}$ \\
\hline Demand shock & $\begin{array}{l}0.12^{*} \\
(0.06)\end{array}$ & $\begin{array}{r}0.12^{*} \\
(0.06)\end{array}$ & $\begin{array}{c}0.10 \\
(0.06)\end{array}$ \\
\hline GDP growth (\%) & - & - & $\begin{array}{l}0.39 \\
(0.28)\end{array}$ \\
\hline Max. LTV ratio & - & - & $\begin{array}{l}3.25 \\
(3.67)\end{array}$ \\
\hline Financial credit as \% GDP & - & - & $\begin{array}{l}1.88 \\
(1.32)\end{array}$ \\
\hline $1980 \mathrm{~s}$ & $\begin{array}{l}-2.02 * * * \\
(0.47)\end{array}$ & $\begin{array}{l}-2.08^{* * *} \\
(0.50)\end{array}$ & $\begin{array}{l}-2.57 * * * \\
(0.51)\end{array}$ \\
\hline 1990s & $\begin{array}{l}-2.80^{* * *} \\
(0.52)\end{array}$ & $\begin{array}{l}-2.82^{* * *} \\
(0.56)\end{array}$ & $\begin{array}{l}-3.11^{* * *} \\
(0.69)\end{array}$ \\
\hline $\begin{array}{l}\text { Log L } \\
\text { Wald } \chi^{2}(25 / 28)\end{array}$ & $\begin{array}{l}-101.47 \\
1145.5 \\
(0.000)\end{array}$ & $\begin{array}{l}-101.94 \\
1127.6 \\
(0.000)\end{array}$ & $\begin{array}{l}-98.93 \\
1246.9 \\
(0.000)\end{array}$ \\
\hline
\end{tabular}

\section{Notes:}

Estimated by generalised least squares, weighted by civilian employment; country dummies included; standard errors in parentheses. $* * *=1 \%, * *=5 \%, *=10 \%$ significance. $\mathrm{N}=63$ (21 countries in 1975 , 1985, 1995).

The financial repression literature in general suggests that household saving rates are negatively associated with indicators of liberalised credit markets, such as higher credit as a percentage of GDP or the maximum loan-to-value ratio, if higher deposits or own finance are required for purchase of consumer durables in less liberalised credit markets. However, as Jappelli and Pagano (1994) point out, these indicators are imperfect measures of underlying market liberalisation and, moreover, the development of credit market institutions may be associated with greater volumes of savings in formal, measurable, channels. The reason for including these variables here is that several of these countries have undergone significant changes in their credit and capital markets over the period. This last point also reiterates that all the specifications in this paper include country and time dummies - identification comes from within-group (country) 
changes, not from pure cross-country differences in institutions and social security regimes. This may be one reason why our results differ from some other studies.

The estimates in Table 2 suggests that a higher contribution rate to the public programme (column 1) and a higher public replacement rate (column 2) raise household saving rates. The coefficients are weakly significant, but not large. These results are of course not consistent with the standard LCH-based substitutability hypothesis but they are not unknown in the cross-country/time series literature, as similar findings based on time series data led Feldstein (1974) to develop the induced retirement hypothesis. Household saving rates are strongly positively associated with variations in the support ratio, as theory would suggest. The positive association with demand shocks is also consistent with theory. There are large country-specific effects (not included) and evidence of a fall in household saving rates, ceteris paribus, in the later decades relative to the 1970s. Finally, the financial repression variables do not add explanatory power.

Table 3 presents our preferred specifications where social security programme design features are included. From the discussion in the Section 2, the offset should be be greatest where the public programme is a close substitute to private saving. This substitutability, I argued, is highest where $(1-\alpha)$ is low (i.e. Pension tax is low) and $(r-$ $G)$ is also low (i.e. IRR at $\mathbf{6 5}$ or IRR is high). So we should expect a positive impact of pension tax on household saving and a negative impact of IRR at 65 on saving.

These predictions are almost exactly confirmed by Table 3, with well-specified parameter values. A higher pension tax component is associated with higher household saving, whereas a higher average IRR on contributions reduces saving. Columns (1) and (2) differ in using the calculated IRR at age 65 and the IRR based on actual retirement date. There is little difference in parameter values between the two measures, and use of IRR at 65 is probably preferable simply because the IRR at actual retirement date may be affected by any induced retirement effect and because the likelihood is also improved. Including the pension replacement rate in the regression (not shown) does not affect these parameter estimates or their significance and the replacement rate variable continues to have the 'wrong' sign.

As before, the support ratio is positively and strongly associated with household saving, there are time effects (larger relative to the results in Table 2) and demand shocks enter with the correct sign. The two variables concerning the parameters of the retirement regime appear to have no effect on household saving. 
Table 3

Household saving rates, by measures of social security programme design

\begin{tabular}{|c|c|c|c|}
\hline $\begin{array}{l}\text { Dep. Variable: } \\
\text { Household saving rate }\end{array}$ & $\begin{array}{c}(1) \\
\text { Coeff. } \\
\text { (Std. Err) }\end{array}$ & $\begin{array}{c}(2) \\
\text { Coeff. } \\
\text { (Std. Err) }\end{array}$ & $\begin{array}{c}\text { (3) } \\
\text { Coeff. } \\
\text { (Std. Err) }\end{array}$ \\
\hline Pension tax & $\begin{array}{l}0.64^{* * *} \\
(0.19)\end{array}$ & $\begin{array}{l}0.57 * * * \\
(0.19)\end{array}$ & $\begin{array}{l}0.68 * * * \\
(0.17)\end{array}$ \\
\hline IRR at 65 & $\begin{array}{l}-1.16^{* * *} \\
(0.21)\end{array}$ & - & $\begin{array}{l}-1.11^{* * *} \\
(0.20)\end{array}$ \\
\hline IRR & - & $\begin{array}{l}-1.09 * * * \\
(0.24)\end{array}$ & - \\
\hline Support ratio & $\begin{array}{l}7.96^{* * *} \\
(0.99)\end{array}$ & $\begin{array}{l}7.27^{* * *} \\
(1.00)\end{array}$ & $\begin{array}{l}8.49^{* * *} \\
(1.01)\end{array}$ \\
\hline Retirement test index & $\begin{array}{l}-0.80 \\
(0.87)\end{array}$ & $\begin{array}{l}-0.79 \\
(0.92)\end{array}$ & $\begin{array}{l}-0.34 \\
(1.00)\end{array}$ \\
\hline Earliest state pension age & $\begin{array}{l}-0.25 \\
(0.18)\end{array}$ & $\begin{array}{l}-0.20 \\
(0.19)\end{array}$ & $\begin{array}{l}-0.26 \\
(0.18)\end{array}$ \\
\hline Demand shock & $\begin{array}{l}0.12^{* *} \\
(0.05)\end{array}$ & $\begin{array}{r}0.13^{*} \\
(0.06)\end{array}$ & $\begin{array}{c}0.08 \\
(0.05)\end{array}$ \\
\hline GDP growth (\%) & - & - & $\begin{array}{c}0.35 \\
(0.23)\end{array}$ \\
\hline Max. LTV ratio & - & - & $\begin{array}{l}6.38 * * \\
(2.87)\end{array}$ \\
\hline Financial credit as \% GDP & - & - & $\begin{array}{l}1.63 \\
(1.30)\end{array}$ \\
\hline $1980 \mathrm{~s}$ & $\begin{array}{l}-3.98^{* * *} \\
(0.55)\end{array}$ & $\begin{array}{l}-3.77 * * * \\
(0.58)\end{array}$ & $\begin{array}{l}-4.69 * * * \\
(0.56)\end{array}$ \\
\hline 1990s & $\begin{array}{l}-3.82 * * * \\
(0.46)\end{array}$ & $\begin{array}{l}-3.55^{* * *} \\
(0.47)\end{array}$ & $\begin{array}{l}-4.23^{* * *} \\
(0.57)\end{array}$ \\
\hline $\begin{array}{l}\text { Log L } \\
\text { Wald } \chi^{2}(28 / 31)\end{array}$ & $\begin{array}{l}-90.15 \\
1668.2 \\
(0.000)\end{array}$ & $\begin{array}{l}-93.14 \\
1511.4 \\
(0.000)\end{array}$ & $\begin{array}{l}-85.43 \\
1947.8 \\
(0.000)\end{array}$ \\
\hline
\end{tabular}

\section{Notes:}

Estimated by generalised least squares, weighted by civilian employment; country dummies included; standard errors in parentheses. $\quad * * *=1 \%, * *=5 \%, *=10 \%$ significance. $\mathrm{N}=63$ (21 countries in 1975 , 1985, 1995).

Column (3) adds the financial repression variables and GDP growth. The latter has the 'correct' sign but is insignificant, and also reduces the significance of 'demand shocks', suggesting some collinearity. One of the financial repression variables is also significant, albeit the positive sign is not consistent with the standard argument that higher loan-to-value ratios reduce the need for saving (for example, for deposits and part-self finance of house purchases). Moreover, inclusion of these additional variables also heightens the reduction in saving in the 1980s and 1990s relative to the 1970s. 
Given inevitable measurement problems in the calculation of these indicator variables, the results in Table 3 (especially when compared to Table 2) are perhaps surprisingly conclusive in suggesting that the design of social security programmes matters if we are to understand the impact of such programmes on household saving rates.

\subsection{Impact of programme design on age-activity rates}

Table 4 presents age-activity rate (labour force participation rate) regressions for the same countries and data period for older workers. The focus of the current paper is not on employment per se (see Disney, 2004). ${ }^{9}$ However given the induced retirement issue and, as described in Section 2, the generic treatment of social security programmes as a form of tax in the standard empirical literature on employment/unemployment and social security programmes, it is interesting to examine some results. Here, the priors (see Section 2.2) are effectively the reverse of those in the saving regressions, since it is 'tax' component rather than the 'saving' component of the programme that is expected to have the larger impact. So the underlying hypothesis is that a lower value of pension tax and a higher value of IRR at $\mathbf{6 5}$ induce greater participation because they reduce the 'tax component' of the social security programme, thereby making work more attractive. This is because they lower $(1-\alpha)$ and $(r-G)$ respectively (see Section 2.1). ${ }^{10}$ Likewise, and in standard fashion, a higher value of Pension RR might reduce participation rates among older workers (although perhaps inducing higher participation earlier in the working life in order to increase eligibility). ${ }^{11}$ A more stringent retirement test index might induce greater participation among older people pre-social securityage, since they should substitute work in the period before pension age for work after. A higher value of the earliest pension age should probably raise economic activity rates among age groups close to that age.

For the other control variable, a positive coefficient on demand shocks is anticipated; union density is a traditional control variable in cross country regressions, possibly having an adverse impact on employment and therefore economic activity. The employment protection index has uncertain effects a priori (see Nickell and Layard,

\footnotetext{
${ }^{9}$ The results differ slightly from that paper by reason of estimation method and minor data corrections. 10 This abstracts from the adverse income effect arising from a higher tax burden on the household. However, it is arguable that, for older households, the substitution effect should outweigh the income effect - see, again, Sheshinski (1978).

${ }_{11}$ Among younger workers, the 'tax component' of the programme may still be pertinent but the relevant 'outside option' should be UI benefits or equivalent.
} 
1999) although we might expect differential effects for men and women given likely tenures - protecting the jobs of older men with perhaps the opposite effect on groups, such as women, with more fragmented career histories. Note again that the equations contain fixed effects, so that within-group variation is driving the parameter estimates.

With these in mind, what does Table 4 show? For women aged 50-54 and 55-59, the results almost all conform with the priors, which is again fairly striking given the limited number of degrees of freedom and the nature of the indicators used to proxy underlying pension design characteristics. Specifically, a lower value of the pension tax raises economic activity rates (although the result is not significant for age group 55-59) and a higher value of IRR at 65 significantly raises economic activity rates for both age groups. A more generous replacement rate on pension benefits significantly lowers economic activity rates. The positive sign on the retirement test index is also consistent with priors although the normal pension age has no impact.

The time dummies confirm that there is a trend towards rising economic activity rates among older women (once we condition on the social security programme variables). Demand shocks are positively signed but insignificant, union density negative but also insignificant. Interestingly, the severity of the employment protection index reduces economic activity rates among older women - not significantly, but the contrast with men is described below. Overall, however, the results for women strikingly confirm most of the original hypotheses.

For men, the results do not confirm the hypothesis that the design of the social security programme matters (at least, according to priors). True, the replacement rate has the predicted adverse impact on economic activity, and the employment protection index has the expected positive sign. Demand shocks now enter significantly and positively for 50-54 year old men. However the two measures of the 'tax component' of the social security programme enter either insignificantly or perversely. It should be noted that the same perverse or insignificant results apply if we enter the 'traditional' measures of the tax wedge, including the contribution rate (not shown here, but see Disney, 2004, for some illustrations). Insignificance can be explained simply by the well-known result that men's participation is less responsive to post-tax wages than women's, but the perverse signs, although not universal, cannot so easily be explained.

Other, plausible, parameters in columns (3) and (4) of Table 4 suggest that there is a downward trend in men's participation over time, especially among the 55-59 year 
olds, and on contrast to women. In addition, increased strength of the employment protection legislation is associated with higher economic activity rates, in complete contrast to women, suggesting that, on balance, such legislation protects workers with longer tenures.

Table 4

Age-activity rates of older workers, by measures of social security programme design

\begin{tabular}{|l|c|c|c|c|}
\hline & $(1)$ & $(2)$ & $(3)$ & $(4)$ \\
Dep. Variable & Women & Women & Men & Men \\
Age activity rate & $50-54$ & $55-59$ & $50-54$ & $55-59$ \\
\hline \multirow{4}{*}{ Pension tax } & & & & \\
& $-1.34^{* * *}$ & -0.35 & 0.20 & $1.60^{* * *}$ \\
Pension RR & $(0.37)$ & $(0.30)$ & $(0.17)$ & $(0.29)$ \\
IRR at 65 & $-0.20^{* * *}$ & $-0.17^{* * *}$ & $-0.14^{* * *}$ & $-0.14^{* * *}$ \\
& $(0.07)$ & $(0.05)$ & $(0.03)$ & $(0.05)$ \\
Retirement test index & $0.91^{* *}$ & $0.89^{* * *}$ & $-0.54^{* * *}$ & -0.44 \\
& $(0.36)$ & $(0.29)$ & $(0.17)$ & $(0.28)$ \\
Earliest state pension age & $5.07^{* * *}$ & $4.59^{* * *}$ & $2.29^{* *}$ & $4.39^{* * *}$ \\
Demand shocks & $(1.97)$ & $(1.60)$ & $(0.91)$ & $(1.53)$ \\
& 0.19 & -0.01 & $0.53^{* * *}$ & -0.09 \\
Union density & $(0.38)$ & $(0.30)$ & $(0.18)$ & $(0.18)$ \\
& 0.19 & 0.10 & $0.17^{* * *}$ & $0.17^{* * *}$ \\
Employment protection index & $(0.12)$ & $(0.10)$ & $(0.06)$ & $(0.29)$ \\
& -0.07 & -0.06 & 0.07 & 0.03 \\
1980s & $(0.11)$ & $(0.09)$ & $(0.05)$ & $(0.08)$ \\
& $(2.06$ & -1.31 & $3.73^{* * *}$ & $5.38^{* * *}$ \\
1990s & $8.89^{* * *}$ & $(1.63)$ & $(0.93)$ & $(1.55)$ \\
& $(1.06)$ & $4.44^{* * *}$ & $-1.42^{* * *}$ & $-6.56^{* * *}$ \\
& $19.00^{* * *}$ & $11.76^{* * *}$ & $(0.49)$ & $(0.82)$ \\
\hline Log likelihood & $(1.14)$ & $(0.92)$ & $(0.53)$ & $(0.88)$ \\
Wald $\chi^{2}$ (30) & & & & \\
\hline
\end{tabular}

Notes:

Estimated by generalised least squares, weighted by civilian employment; country dummies included; standard errors in parentheses. $* * *=1 \%, * *=5 \%, *=10 \%$ significance. $\mathrm{N}=63$ (21 countries in 1975, 1985, 1995).

\subsection{Simulating social security reforms}

The estimates in Section 4.1 suggested that there is a strong link between the design of the social security programme and the household saving rate. Using these indicators of programme design, how would a given social security reform affect household saving rates? In this section, I simulate some simple social security reforms to 
show how changing the programme design might affect household saving rates given the parameter values derived earlier.

The link between low saving and a social security programme has been at the heart of the US debate on social security reform, although it is fair to say that elsewhere in the world, reforming social security in order to raise the saving rate has been very much a secondary consideration compared to other pressing motives for reform (rapid ageing, and the sustainability of the public finances). It is of course true that the development of a social security programme lowers the measured saving rate simply because social security contributions are not treated as 'saving' in conventional national accounts (Jappelli and Modigliani, 2003). 'Privatizing' the social security programme by replacing it with, for example, a system of individual private retirement accounts would therefore raise the measured household saving rate. Moreover, as Gokhale, Kotlikoff and Sabelhaus (1996) point out, the increasing annuitization of retirement wealth implied by the development of pension programmes will also reduce other measured wealth in the economy. In their analysis, the fall in the US saving rate since the 1950s has been driven largely by demographics, by cohort-specific changes in preferences for consumption, and by growing annuitization of wealth. Engen and Gale (1997), in their survey of studies of social security reform and saving, also add caution to the idea that social security reform will significantly change household saving rates, once we allow for these measurement issues. However, we should not focus on what are essentially reforms that raise saving by redefining programme components as saving.

As a simple first step, we can examine the residual 'country effects' once we control the effect of the independent regressors. Re-estimating the equation in Table 3, column (3) and suppressing the constant, the marginal effects of the country dummies in the panel estimates are illustrated in Figure 1.

From Figure 1, it is apparent that a number of the 'Anglo-Saxon' countries have negative intercepts whereas (particularly) some of the Mediterranean countries are characterised by above-average saving rates. Note in particular the US, where the country-specific saving rate is $7 \%$ below the average. However the actual US household saving rate was only $4.5 \%$ below the average over the period, suggesting that a combination of demographics, the design of the social security programme in the US and the other independent variables raised the US saving rate relative to this crude counterfactual. 
Figure 1

Household saving rates: country effects

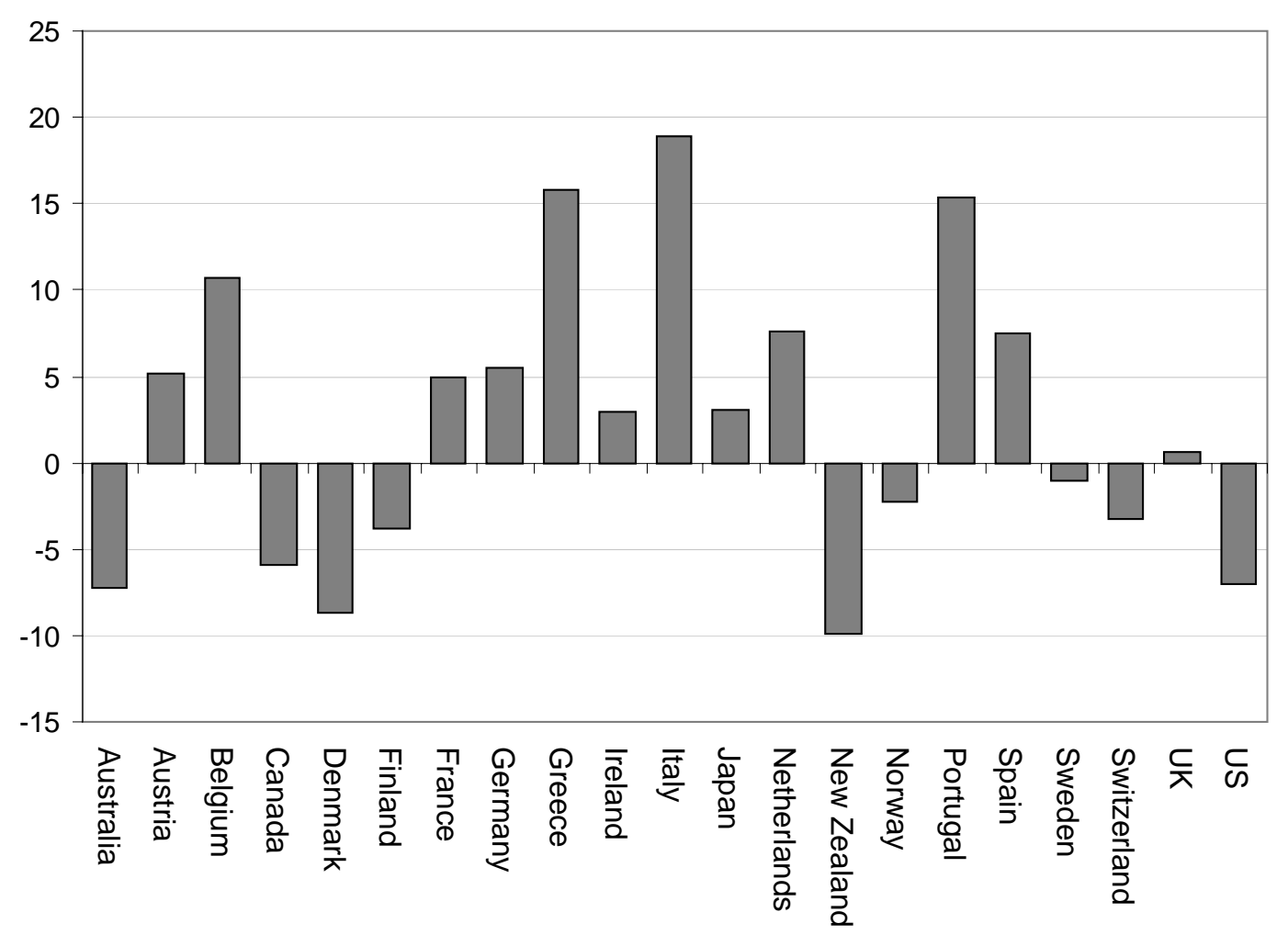

Reflection on these US characteristics provides a simple explanation of why this is the case. The US support ratio is somewhat above average, due to more favourable demographic circumstances than other countries (especially in Europe) in the past, and higher labour force participation of, particularly, women. As Tables 2 and 3 show, this has a strong impact on household saving. Moreover, the US social security programme's design is such as to reduce the offset on saving: the internal rate of return has been below average (at least in the first two decades - see Table A3) and the 'bend' points and other non-linearities in the programme provide departures from an 'actuarial-based' programme. Both characteristics, by the reasoning here, reduces the substitutability of the programme for private household saving.

A simple method of examining the reform of social security programmes is to give a particular country the specific characteristics of another country's social security programme whilst retaining the country's other characteristics (e.g. demographics, financial market development). This can be illustrated by reference to the United States (experiments for other countries would obtain similar magnitudes). 
Assuming outright abolition of social security is not feasible, we might consider a stylised reform in which social security was reduced to the bare minimum of an incometested 'floor' to supplement a largely privatised system, such as is the case in Chile. Within the data set, Australia is the closest approximation to this with an average replacement rate some 15-20 percentage points below that of the US and extensive means-testing. We can recalculate the variable 'pension tax' for the US to have an Australian-style average replacement rate and value of $(1-\alpha)$ and, to heighten the comparison, set the internal rate of return at 65 to zero. By the argument of preceding sections, this would be a social security programme with very little substitutability for household saving, thereby raising the latter. Implementing this experiment, I calculate that this would only have a significant effect on US household saving in the last period, raising it by 0.6 percentage points from $5.2 \%$ to $5.8 \%$ (which is a $12 \%$ increase in the saving rate).

Conversely, to illustrate where the US lies in the spectrum of programmes, we could have a counterfactual where the US programme is akin to a more 'Bismarckian' programme with a minimal 'pension tax' component and an internal rate of return at the $75^{\text {th }}$ percentile of the observed distribution of rates of return in the sample. By the analysis here, this should lower the household saving rate in the US still further. In fact, this reform has very little effect in the last decade, because the IRRs are closely bunched and the US's IRR is not particularly low. In the first two decade, however, had the US had such a generous system, the household saving rates would have been 0.5 percentages points lower (7.7 rather than 8.2) and 1.3 percentage points (5.5 rather than 6.8) decreases of $6 \%$ and $19 \%$ respectively. These are not trivial numbers but they do suggest that, simple definitional considerations aside, social security reform is not a 'magic bullet' for changing household saving rates - that is, once we consider practical social security regime changes and not hypothetical simulations where social security is abolished or where contributions to programmes are redefined as 'saving'.

\section{Conclusion}

This paper examines the impact of the design of social security programmes on household saving rates and the age-activity rates of older workers, using a short panel of OECD countries. Previous literature that considered the impact on social security programmes on household economic activity, with very few exceptions, either treated social security solely as a substitute for private saving or, if interested in employment and 
unemployment trends, simply as a tax, using proxies for the generosity or cost of the programme accordingly. The contention here is that social security contributions are neither simply another tax on wages nor a pure form of retirement saving.

By measuring how far returns to social security within and across generations differ from those in an 'actuarial' scheme in any given setting, we are able to provide separate indicators of social security programme design. Using these indicators, the paper shows that, the closer the social security programme is to an 'actuarial-based' programme, the greater its substitutability for private retirement saving and the lower the impact on age-activity rates, at least for older women. In contrast, a social security programme that is more like a tax-and-transfer programme, with little link between individual benefits and contributions, has little effect on saving but possibly adverse effects on labour force participation.

In the final section, I focus on how actual social security reforms might affect household saving rates, using the United States characteristics to illustrate the point. The effects of social security reform on saving are significant, although perhaps not as large as some reform advocates suggest. But it should be borne in mind that reforms that generate large effects on private saving often use highly stylised models of social security programmes, and that much of the measured effect on private saving rates comes from accounting changes rather than changes in household behaviour. It would be interesting to focus on household data sets to pursue this issue further, and a few studies now focus on reforms to provide the 'policy experiments' required. So far, however, such studies have exploited the reform to estimate saving responses, but not analysed the content of the reforms themselves. The question of whether policy reforms can therefore be designed to increase saving remains an open issue. 


\section{References}

Alessie, M., Kapteyn, A. and Klijn, F. (1997) 'Mandatory pensions and personal savings in the Netherlands', De Economist, 145, 3, 291-324.

Attanasio, O. and Brugiavini, A. (2003) 'Social security and households' saving', Quarterly Journal of Economics, 118, August, 1075-1119.

Attanasio, O. and Rohwedder, S. (2003), 'Pension Wealth and Household Saving: Evidence from Pension Reforms in the U.K.', American Economic Review, 93(5), 14991521.

Barro, R. and MacDonald, G. (1979) 'Social security and consumer spending in an international cross section', Journal of Public Economics, 11, June, 275-289.

Bertola, G., Disney, R. and Grant, C. (eds) (1996) The Economics of Consumer Credit, forthcoming, MIT Press, Cambridge: Mass.

Blanchard, O. and Wolfers, J. (2000) 'The role of shocks and institutions in the rise of European unemployment: The aggregate evidence', Economic Journal, 110, March, pp.C1-C33.

Blöndal, S. and Scarpetta, S. (1998) 'The retirement decisions in OECD countries', OECD Economics Department Working Paper, No. 202, Paris.

Boeri, T., Börsch-Supan, A. and Tabellini, G. (2001) 'Would you like to shrink the welfare state? The opinions of European citizens', Economic Policy, 16, April, 7-50.

Bottazza, R., Jappelli, T. and Padula, M. (2004) 'Retirement expectations, pension reforms, and their impact on private wealth accumulation', mimeo, University of Salerno.

Callen, T. and Thimann, C. (1997) 'Empirical determinants of household saving: Evidence from OECD countries', International Monetary Fund Working Paper WP/97/181, Washington D.C.

Casamatta, G., Cremer, H. and Pestieau, P. (2000) 'Political sustainability and the design of social insurance' Journal of Public Economics, 75, 341-364.

Disney, R. (2000a) 'Declining public pensions in an era of demographic ageing: Will private provision fill the gap?', European Economic Review, 44, March/April, 957-973.

Disney, R. (2000b) 'The impact of tax and welfare policies on employment and unemployment in OECD countries', International Monetary Fund Working Paper WP/00/164, Washington DC.

Disney, R. (2004) Are contributions to public pension programmes a tax on employment?' Economic Policy, 39, July, 269-311, and discussion thereof.

Dominitz, J., Manski, C. and Heinz, J. (2003) 'Will social security be there for you? How Americans perceive their benefits', National Bureau of Economic Research Working Paper w9798, June.

Engen, E. and Gale, W. (1997) 'Effects of social security reform on private and national saving' in Sass, S. and Triest, R. (eds) Social Security Reforms: Links to Saving, Investment and Growth, Conference Series No. 41, Federal Reserve Bank of Boston, Mass.

Feldstein, M. (1974) 'Social security, induced retirement and aggregare capital accumulation', Journal of Political Economy, 82, 5, 905-926. 
Feldstein, M. (1980) 'International differences in social security and saving', Journal of Public Economics, 14, 225-244.

Feldstein, M. (1987) 'Should social security benefits be means-tested?' Journal of Political Economy, 95, June, 468-484.

Feldstein, M. (1996) 'Social security and saving: New time series evidence', National Tax Journal, 49, June, 151-164.

Gokhale, J., Kotlikoff, L. and Sabelhaus, J. (1996) 'Understanding the postwar decline in US saving: A cohort analysis', Brookings Papers on Economic Activity, 1, 315-390.

Hubbard, G. (1986) 'Pension wealth and individual saving', Journal of Money, Credit and Banking, 18, 2, 167-178.

Jappelli, T. and Modigliani, F. (2003) 'The age-saving profile and the life-cycle hypothesis', forthcoming, The Collected Papers of Franco Modigliani, Volume 6: MIT Press.

Jappelli, T. and Pagano, M. (1994) 'Saving, growth and liquidity constraints', Quarterly Journal of Economics, 109, February, 83-109.

Koskela, E. and Viren, M. (1983) 'Social security and household saving in an international cross section', American Economic Review, 73, 1, 212-216.

Kotlikoff, L. (1979) 'Testing the theory of social security and life cycle accumulation', American Economic Review, 69, June, 396-410.

Leimer, D. and Lesnoy, S. (1982) 'Social security and private saving: New time-series evidence', Journal of Political Economy, 90, June, 606-629.

Lindbeck, A. and Persson, T. (2003) 'The gains from pension reform', Journal of Economic Literature, XLI, March, pp.74-112.

Loayza, N., Schmidt-Hebbel, K. and Serven, L. (2000) 'What drives private saving across the world?', Review of Economics and Statistics, 82, May, 165-181.

Modigliani, F. (1986) 'Life cycle, individual thrift and the wealth of nations', American Economic Review, 76, 3, 297-313

Nickell, S. (2004) 'Employment and taxes', CEP Discussion paper no. 634, May, London School of Economics.

Nickell, S. and Layard, R. (1999) 'Labour market institutions and economic performance', in O. Ashenfelter and D. Card (eds) Handbook of Labor Economics Vol 3, Amsterdam: North Holland.

Nickell, S, Nunziata, L. and Ochel, W. (2005) 'Unemployment in the OECD since the 1960s: What do we know?’ Economic Journal, 112, January.

OECD (1990) 'Employer versus employee taxation: the impact on employment', Employment Outlook, July, Paris.

Ooghe, E., Schokkaert, E. and Flechet, J. (2003) 'The incidence of social security contributions: An empirical analysis', Empirica, 30, 81-106.

Pissarides, C. (1998) 'The impact of employment tax cuts on unemployment and wages: The role of unemployment benefits and tax structure', European Economic Review, 42, 155-183.

Sheshinski, E. (1978) 'A model of social security and retirement decisions', Journal of Public Economics, 10, 337-360. 


\section{Appendix}

\section{Definitions of variables}

Age-activity rate: Proportion of age group $i$ at $t$ economically active. Derived from ILO statistics website $L A B O R S T A$ and from extrapolation where annual data unavailable e.g. Switzerland, UK.

Household saving rate: Average household saving rate as a \% of GDP over the decade. Derived from OECD online data and (for 1970s) from Callen and Thimann (1997).

Pension RR: These are the average expected gross public pension replacement rates constructed by Blöndal and Scarpetta (1998), Table III.3 for 1961, 1975 and 1995. They are stylised indicators of what a 55 year old at each date could expect, in terms of public pension benefits relative to earned income at retirement, if that individual started work at age 20 (ibid, Box III.1). By interpolation (with adjustments where pension reforms seem to have had significant impacts, as in the United Kingdom in the late 1970s) and by extrapolation to the mid-1950s, I have used these data to construct mid-decade estimates of expected replacement rates for a 55 year old in 1955, 1965, 1975, 1985 and 1995. The resulting data are given in Table A2. It is both striking how much replacement rates differ across countries, and also how, in many countries, these rates have increased systematically over time.

The support ratio: ILO data on activity rates gives the ratio of actual workers aged 15-59 to people aged over 60. To convert this ratio into an effective support ratio, I make a couple of additional assumptions. First, I remove all workers aged under 20 and over 60, on the grounds that their contribution to total contribution revenue is likely to be low (low incomes and/or low hours). Secondly, it should not be assumed that all people over 60 receive a pension from the public programme - as described earlier, most countries have a contribution requirement underpinning eligibility for benefits. As an approximation, I take all men as eligible for a pension, and the proportion of women eligible as equivalent to the highest rate of participation observed in each decade's crosssection of participation rates for women. So, for example, if the highest 5 year age band participation rate is $70 \%$, I assume that this percentage will receive a full pension. Since non-contributors are generally entitled to some benefits, especially widows (and widowers without their own pension rights), I use information on rights to survivors benefits (which varies across these countries from $0 \%$ to $100 \%$ of the original award) from the US Social Security Administration's Survey of country pension programmes.

The data are depicted in Table A1.

Actual contribution rates, although sometimes used in 'tax wedge' calculations, are almost useless for purposes of estimating effective tax rates. Some countries, such as Australia and New Zealand, do not levy separate contributions at all - in these countries, public pensions are financed out of general taxation. In other countries, such as Greece and Italy, effective contribution rates have understated the 'true' costs of paying pensions, for many years being subsidised by direct budgetary transfers and borrowing. Finally, in some other countries, assets are accumulated within the public pension programme (such as the US social security Trust Fund), which implies that the measured contribution rate exceeds that required to finance current pension expenditure. In contrast, some countries, such as Japan, have systematically run down accrued public pension assets 
over time. Finally, some countries (such as the United Kingdom) can more-or-less automatically adjust contribution rates to finance outgoings, whereas other countries (such as the United States) require legislation to vary contribution rates, and approval is not always forthcoming.

\section{Pension contribution is Pension RR divided by The Support Ratio}

Pension tax: Blöndal and Scarpetta (1998) report expected pension replacement rates for four categories of 55 year old contributors - single people and couples, on average earnings and at $66 \%$ of average earnings. These calculations capture two dimensions of departures from intragenerational actuarial fairness - that contributors at different earning levels are treated differently and that contributors in couples may or may not get differential benefits relative to contributions (especially when their partners are not working). To give an example from the Blöndal and Scarpetta data, the 1995 figures for replacement rates for Belgium are singles at mean earnings: $60 \%$, at $66 \%$ of mean earnings: $60 \%$; couples at mean earnings: $75 \%$, at $66 \%$ of mean earnings: $75 \%$. Clearly in one dimension there is approximate actuarial fairness (earnings level) but not in another (singles v. couples). Compare this with Australia where the respective replacement rates are $37 \%, 24 \%, 62 \%$ and $41 \%$, and where there are departures in both dimensions.

The following indicator is constructed: if the four Blöndal and Scarpetta expected replacement rates are identical for each country-time observation, Pension tax is zero. If the rates vary, then the coefficient of variation of the replacement rates gives an approximate measure of the departure from actuarial fairness in each country and time period (the normalisation does not affect the ranking - a similar ordering would occur if, say, the mean square error was used).

IRR at 65: For each of the 22 countries examined in this study, the average replacement rates serve two purposes. First, they permit us to construct expected pension benefits for three cohorts of individuals in each country - those aged 55 in respectively, 1975, 1985 and 1995. I term these three cohorts as those born in 1920, 1930 and 1940, who are assumed to retire in, respectively, the mid-1980s, 1990s and 2000s.

Given these values, the internal rates of return are constructed as follows. In each decade, the contribution rate is applied to average earnings, which grow in each decade in real terms at the average rate reported in OECD data. It is assumed that the first cohort, born 1920, only starts contributing in 1950 (to capture the advantage accruing to the earliest generation) but that the subsequent generations contribute into their fourth (or even fifth) decade of work, depending on average retirement age. The replacement rate is then applied to real earnings at retirement, and the pension is increased in line with subsequent earnings growth if earnings indexation is in place. Many countries indexed benefits to earnings until the 1980s; thereafter shifts to price indexation or partial indexation are common. Expected age of death is taken from Blöndal and Scarpetta (checked on ILO data) with survivors' benefits paid at the appropriate rate for that country until the spouse's expected age of death.

The internal rate of return is then computed as that rate of return at which the present value of the (negative) stream of contributions paid is equal to the present value of the (positive) stream of pension benefits. In Disney (2004), I present some calculations from other sources of IRRs for particular cohorts to compare with these numbers (e.g. from 
Germany, Italy and the UK - most other countries in this sample have had no comparable calculations to my knowledge).

Retirement test index and Earliest pension age are described in the text.

Demand shocks is the Blanchard-Wolfers (2000) measure of changes in aggregate demand, as described at http://econ-wp.mit.edu/RePEc/2000/blanchar/harry data/.

Union density, as described by Nickell and Layard (1999) contains only cross-country variation in that source. Time variation for this variable was obtained by exploiting information on union density across countries over time held at Cornell University. See the document: http://www.ilr.cornell.edu/library/downloads/FAQ/UNIONSTATS2002.pdf.

Employment protection index: This variable is the time-varying index constructed by Blanchard and Wolfers (2000) and described at their website cited above.

Table A1

Effective economic support ratios (\%), 1955-95

\begin{tabular}{lccccc}
\hline Country & 1955 & 1965 & 1975 & 1985 & 1995 \\
\hline Australia & & & & & \\
Austria & 2.63 & 2.68 & 2.82 & 2.80 & 2.78 \\
Belgium & 2.61 & 2.12 & 2.12 & 2.28 & 2.28 \\
Canada & 2.12 & 1.93 & 1.99 & 2.07 & 1.96 \\
Denmark & 3.08 & 3.07 & 3.20 & 3.20 & 3.05 \\
Finland & 2.82 & 2.37 & 2.46 & 2.76 & 2.79 \\
France & 4.12 & 3.26 & 3.13 & 2.94 & 2.66 \\
Germany & 2.46 & 2.29 & 2.46 & 2.53 & 2.34 \\
Greece & 2.95 & 2.37 & 2.45 & 2.62 & 2.46 \\
Ireland & 3.22 & 2.44 & 2.09 & 2.05 & 2.08 \\
Italy & 2.21 & 1.94 & 2.21 & 2.37 & 2.61 \\
Japan & 2.90 & 2.43 & 2.35 & 2.18 & 2.00 \\
Luxembourg & 4.42 & 4.05 & 3.68 & 2.94 & 2.25 \\
Netherlands & 2.50 & 2.10 & 2.05 & 2.27 & 2.22 \\
New Zealand & 2.27 & 2.27 & 2.37 & 2.53 & 2.56 \\
Norway & 2.77 & 2.63 & 2.78 & 2.83 & 2.95 \\
Portugal & 2.35 & 1.96 & 2.03 & 2.13 & 2.32 \\
Spain & 2.63 & 2.20 & 2.61 & 2.60 & 2.34 \\
Sweden & 3.16 & 2.55 & 2.61 & 2.46 & 2.22 \\
Switzerland & 2.35 & 2.05 & 2.06 & 2.08 & 2.19 \\
UK & 2.63 & 2.39 & 2.35 & 2.43 & 2.41 \\
US & 2.27 & 2.09 & 1.98 & 2.01 & 2.10 \\
& 2.68 & 2.53 & 2.53 & 2.63 & 2.75 \\
\hline Average & & & & & \\
\hline
\end{tabular}

Source: ILO online data and own calculations as described in Disney (2004). 
Table A2

Effective contribution rates to social security programmes in OECD countries 1955-95 $(\%)$

\begin{tabular}{lrrrrr}
\hline Country & 1955 & 1965 & 1975 & 1985 & 1995 \\
\hline & & & & & \\
Australia & 7.3 & 9.2 & 11.6 & 13.2 & 14.7 \\
Austria & 30.5 & 37.5 & 37.5 & 34.9 & 34.8 \\
Belgium & 34.2 & 37.1 & 35.4 & 33.3 & 34.4 \\
Canada & 10.2 & 12.0 & 14.1 & 15.1 & 16.9 \\
Denmark & 12.7 & 16.2 & 17.2 & 17.9 & 20.1 \\
Finland & 8.5 & 13.6 & 18.7 & 20.2 & 22.5 \\
France & 20.3 & 24.1 & 25.4 & 25.2 & 27.7 \\
Germany & 20.4 & 25.3 & 24.3 & 21.9 & 22.4 \\
Greece & 15.5 & 25.4 & 38.2 & 48.8 & 57.7 \\
Ireland & 17.4 & 17.9 & 13.1 & 14.4 & 15.2 \\
Italy & 20.7 & 25.0 & 26.4 & 32.5 & 40.0 \\
Japan & 5.6 & 9.0 & 14.7 & 18.1 & 23.2 \\
Luxembourg & 32.0 & 38.1 & 39.1 & 38.1 & 42.1 \\
Netherlands & 14.2 & 17.0 & 20.2 & 18.6 & 17.9 \\
New Zealand & 11.6 & 13.8 & 15.5 & 18.4 & 20.8 \\
Norway & 10.7 & 20.2 & 30.2 & 28.4 & 25.8 \\
Portugal & 32.4 & 37.2 & 29.5 & 30.7 & 35.4 \\
Spain & 15.8 & 19.6 & 19.1 & 30.5 & 45.0 \\
Sweden & 22.9 & 30.8 & 37.4 & 36.3 & 33.9 \\
Switzerland & 10.8 & 15.8 & 22.0 & 20.8 & 20.4 \\
UK & 14.7 & 16.0 & 17.1 & 20.8 & 23.7 \\
US & 14.6 & 17.0 & 19.4 & 20.0 & 20.4 \\
& & & & & \\
\hline Average & 17.4 & 21.7 & 23.9 & 25.4 & 28.0 \\
\hline
\end{tabular}

Source: Author's calculations, using Table A1, interpolated data from Blöndal and Scarpetta (1998), and text equation (2). 
Table A3

Internal Rates of Return to social security programme contributions by cohort: Common retirement age at 65

\begin{tabular}{lrrr}
\hline Country & $\begin{array}{r}\text { Cohort } \\
\text { b.1920 }\end{array}$ & $\begin{array}{r}\text { Cohort } \\
\text { b.1930 }\end{array}$ & $\begin{array}{r}\text { Cohort } \\
b .1940\end{array}$ \\
\hline & & & \\
Australia & 1.63 & -0.01 & 1.19 \\
Austria & 2.71 & 1.05 & 1.11 \\
Belgium & 1.06 & 0.12 & 1.10 \\
Canada & 2.10 & 0.41 & 0.74 \\
Denmark & 1.67 & -0.05 & 1.42 \\
Finland & 5.34 & 1.75 & 1.60 \\
France & 3.03 & 1.03 & 1.20 \\
Germany & 4.58 & 2.35 & 1.34 \\
Greece & 3.04 & 0.14 & 0.60 \\
Ireland & -0.30 & 0.32 & 0.08 \\
Italy & 5.84 & 2.87 & 0.99 \\
Japan & 6.73 & 2.66 & 1.79 \\
Luxembourg & -0.26 & -1.39 & -0.24 \\
Netherlands & 10.32 & 5.67 & 3.32 \\
New Zealand & 0.50 & -0.30 & 0.35 \\
Norway & 2.86 & -0.16 & 1.51 \\
Portugal & 6.80 & 4.34 & 2.66 \\
Spain & 7.04 & 4.42 & 3.59 \\
Sweden & 5.40 & 2.10 & 0.89 \\
Switzerland & 2.56 & 0.09 & -0.53 \\
UK & 0.39 & -0.42 & 0.35 \\
US & 0.45 & -0.41 & 1.09 \\
& & & \\
\hline Average & 3.34 & 1.21 & 1.19 \\
\hline
\end{tabular}

Source: author's calculations 


\section{CESifo Working Paper Series}

(for full list see www.cesifo-group.de)

1477 M. Hashem Pesaran, L. Vanessa Smith and Ron P. Smith, What if the UK had Joined the Euro in 1999? An Empirical Evaluation Using a Global VAR, June 2005

1478 Chang Woon Nam and Doina Maria Radulescu, Effects of Corporate Tax Reforms on SMEs' Investment Decisions under the Particular Consideration of Inflation, June 2005

1479 Panos Hatzipanayotou, Sajal Lahiri and Michael S. Michael, Globalization, CrossBorder Pollution and Welfare, June 2005

1480 John Whalley, Pitfalls in the Use of Ad valorem Equivalent Representations of the Trade Impacts of Domestic Policies, June 2005

1481 Edward B. Barbier and Michael Rauscher, Trade and Development in a Labor Surplus Economy, June 2005

1482 Harrie A. A. Verbon and Cees A. Withagen, Tradable Emission Permits in a Federal System, June 2005

1483 Hendrik Hakenes and Andreas Irmen, On the Long-Run Evolution of Technological Knowledge, June 2005

1484 Nicolas Schmitt and Antoine Soubeyran, A Simple Model of Brain Circulation, June 2005

1485 Carsten Hefeker, Uncertainty, Wage Setting and Decision Making in a Monetary Union, June 2005

1486 Ondřej Schneider and Jan Zápal, Fiscal Policy in New EU Member States - Go East, Prudent Man!, June 2005

1487 Christian Schultz, Virtual Capacity and Competition, June 2005

1488 Yvan Lengwiler and Elmar Wolfstetter, Bid Rigging - An Analysis of Corruption in Auctions, June 2005

1489 Johannes Becker and Clemens Fuest, Does Germany Collect Revenue from Taxing Capital Income?, June 2005

1490 Axel Dreher and Panu Poutvaara, Student Flows and Migration: An Empirical Analysis, June 2005

1491 Bernd Huber and Marco Runkel, Interregional Redistribution and Budget Institutions under Asymmetric Information, June 2005 
1492 Guido Tabellini, Culture and Institutions: Economic Development in the Regions of Europe, July 2005

1493 Kurt R. Brekke and Michael Kuhn, Direct to Consumer Advertising in Pharmaceutical Markets, July 2005

1494 Martín Gonzalez-Eiras and Dirk Niepelt, Sustaining Social Security, July 2005

1495 Alfons J. Weichenrieder, (Why) Do we need Corporate Taxation?, July 2005

1496 Paolo M. Panteghini, S-Based Taxation under Default Risk, July 2005

1497 Panos Hatzipanayotou and Michael S. Michael, Migration, Tied Foreign Aid and the Welfare State, July 2005

1498 Agata Antkiewicz and John Whalley, BRICSAM and the Non-WTO, July 2005

1499 Petr Hedbávný, Ondřej Schneider and Jan Zápal, A Fiscal Rule that has Teeth: A Suggestion for a 'Fiscal Sustainability Council' underpinned by the Financial Markets, July 2005

1500 J. Atsu Amegashie and Marco Runkel, Sabotaging Potential Rivals, July 2005

1501 Heikki Oksanen, Actuarial Neutrality across Generations Applied to Public Pensions under Population Ageing: Effects on Government Finances and National Saving, July 2005

1502 Xenia Matschke, Costly Revenue-Raising and the Case for Favoring Import-Competing Industries, July 2005

1503 Horst Raff and Nicolas Schmitt, Why Parallel Trade may Raise Producers Profits, July 2005

1504 Alberto Bisin and Piero Gottardi, Efficient Competitive Equilibria with Adverse Selection, July 2005

1505 Peter A. Zadrozny, Necessary and Sufficient Restrictions for Existence of a Unique Fourth Moment of a Univariate GARCH(p,q) Process, July 2005

1506 Rainer Niemann and Corinna Treisch, Group Taxation, Asymmetric Taxation and Cross-Border Investment Incentives in Austria, July 2005

1507 Thomas Christiaans, Thomas Eichner and Ruediger Pethig, Optimal Pest Control in Agriculture, July 2005

1508 Biswa N. Bhattacharyay and Prabir De, Promotion of Trade and Investments between China and India: The Case of Southwest China and East and Northeast India, July 2005

1509 Jean Hindriks and Ben Lockwood, Decentralization and Electoral Accountability: Incentives, Separation, and Voter Welfare, July 2005 
1510 Michelle R. Garfinkel, Stergios Skaperdas and Constantinos Syropoulos, Globalization and Domestic Conflict, July 2005

1511 Jesús Crespo-Cuaresma, Balázs Égert and Ronald MacDonald, Non-Linear Exchange Rate Dynamics in Target Zones: A Bumpy Road towards a Honeymoon - Some Evidence from the ERM, ERM2 and Selected New EU Member States, July 2005

1512 David S. Evans and Michael Salinger, Curing Sinus Headaches and Tying Law: An Empirical Analysis of Bundling Decongestants and Pain Relievers, August 2005

1513 Christian Keuschnigg and Martin D. Dietz, A Growth Oriented Dual Income Tax, July 2005

1514 Fahad Khalil, David Martimort and Bruno Parigi, Monitoring a Common Agent: Implications for Financial Contracting, August 2005

1515 Volker Grossmann and Panu Poutvaara, Pareto-Improving Bequest Taxation, August 2005

1516 Lars P. Feld and Emmanuelle Reulier, Strategic Tax Competition in Switzerland: Evidence from a Panel of the Swiss Cantons, August 2005

1517 Kira Boerner and Silke Uebelmesser, Migration and the Welfare State: The Economic Power of the Non-Voter?, August 2005

1518 Gabriela Schütz, Heinrich W. Ursprung and Ludger Wößmann, Education Policy and Equality of Opportunity, August 2005

1519 David S. Evans and Michael A. Salinger, Curing Sinus Headaches and Tying Law: An Empirical Analysis of Bundling Decongestants and Pain Relievers, August 2005

1520 Michel Beine, Paul De Grauwe and Marianna Grimaldi, The Impact of FX Central Bank Intervention in a Noise Trading Framework, August 2005

1521 Volker Meier and Matthias Wrede, Pension, Fertility, and Education, August 2005

1522 Saku Aura and Thomas Davidoff, Optimal Commodity Taxation when Land and Structures must be Taxed at the Same Rate, August 2005

1523 Andreas Haufler and Søren Bo Nielsen, Merger Policy to Promote 'Global Players'? A Simple Model, August 2005

1524 Frederick van der Ploeg, The Making of Cultural Policy: A European Perspective, August 2005

1525 Alexander Kemnitz, Can Immigrant Employment Alleviate the Demographic Burden? The Role of Union Centralization, August 2005

1526 Baoline Chen and Peter A. Zadrozny, Estimated U.S. Manufacturing Production Capital and Technology Based on an Estimated Dynamic Economic Model, August 2005 
1527 Marcel Gérard, Multijurisdictional Firms and Governments' Strategies under Alternative Tax Designs, August 2005

1528 Joerg Breitscheidel and Hans Gersbach, Self-Financing Environmental Mechanisms, August 2005

1529 Giorgio Fazio, Ronald MacDonald and Jacques Mélitz, Trade Costs, Trade Balances and Current Accounts: An Application of Gravity to Multilateral Trade, August 2005

1530 Thomas Christiaans, Thomas Eichner and Ruediger Pethig, A Micro-Level 'Consumer Approach' to Species Population Dynamics, August 2005

1531 Samuel Hanson, M. Hashem Pesaran and Til Schuermann, Firm Heterogeneity and Credit Risk Diversification, August 2005

1532 Mark Mink and Jakob de Haan, Has the Stability and Growth Pact Impeded Political Budget Cycles in the European Union?, September 2005

1533 Roberta Colavecchio, Declan Curran and Michael Funke, Drifting Together or Falling Apart? The Empirics of Regional Economic Growth in Post-Unification Germany, September 2005

1534 Kai A. Konrad and Stergios Skaperdas, Succession Rules and Leadership Rents, September 2005

1535 Robert Dur and Amihai Glazer, The Desire for Impact, September 2005

1536 Wolfgang Buchholz and Wolfgang Peters, Justifying the Lindahl Solution as an Outcome of Fair Cooperation, September 2005

1537 Pieter A. Gautier, Coen N. Teulings and Aico van Vuuren, On-the-Job Search and Sorting, September 2005

1538 Leif Danziger, Output Effects of Inflation with Fixed Price- and Quantity-Adjustment Costs, September 2005

1539 Gerhard Glomm, Juergen Jung, Changmin Lee and Chung Tran, Public Pensions and Capital Accumulation: The Case of Brazil, September 2005

1540 Yvonne Adema, Lex Meijdam and Harrie A. A. Verbon, The International Spillover Effects of Pension Reform, September 2005

1541 Richard Disney, Household Saving Rates and the Design of Social Security Programmes: Evidence from a Country Panel, September 2005 